\title{
De rol van slachtoffercompensatie in de publieke waardering van strafoplegging ${ }^{*}$
}

\author{
Janne van Doorn, Maarten Kunst, Jelle Brands \& Jan de Keijser
}

In de huidige studie is onderzocht in hoeverre de aan- of afwezigheid van slachtoffercompensatie van invloed is op oordelen over straf door het algemene publiek. Uit de resultaten blijkt dat het wel of niet toewijzen van een schadevergoeding in het geval van mishandeling of inbraak er niet toe doet voor de mate waarin het algemene publiek zich kan vinden in de door de rechter opgelegde straf. Het wordt door het publiek wel belangrijk gevonden dat er voor slachtoffers de mogelijkheid bestaat om een schadevergoeding voor immateriële schade in te dienen.

\section{Inleiding}

De toegenomen aandacht voor slachtoffers binnen het strafrechtelijk proces in de afgelopen decennia heeft zich vertaald in tal van slachtoffergerichte projecten en interventies, zoals mediation, mogelijkheden om compensatie te ontvangen, en spreekrecht (bijv. Lens e.a., 2010; Scheirs e.a., 2009; Van der Aa \& Groenhuijsen, 2012; Van der Aa e.a., 2013). De toegenomen aandacht heeft zich ook vertaald in een scala aan onderzoek naar hoe dergelijke procedures en interventies gerelateerd zijn aan tevredenheid met de strafrechtelijke procedure onder slachtoffers (voor een review zie Laxminarayan e.a., 2013). Echter, er is minder bekend over wat het algemene publiek vindt van slachtoffergerichte interventies zoals compensatie (in relatie tot andere aspecten van het strafrechtelijk systeem) en op welke wijze dergelijke interventies hun waardering van het strafrechtelijk systeem beïnvloeden. Het huidige onderzoek poogt daarin meer inzicht te verschaffen.

\section{De punitiviteitskloof}

Bestaand onderzoek dat zich richt op de attitudes en beoordelingen van het algemene publiek met betrekking tot ons strafrechtelijk systeem is vooral gericht op straffen, en laat een algemene ontevredenheid zien. Meer specifiek worden straffen door het Nederlandse publiek (maar ook het publiek in andere westerse landen) veelal als te mild ervaren (bijv. Barber \& Doob, 2004; De Keijser e.a., 2007; Elffers \& De Keijser, 2004; Hough \& Roberts, 1998; Hutton, 2005; Mattinson \& Mirrlees-Black, 2000; Roberts \& Hough, 2002; De Keijser \& Elffers, 2009; Dekker e.a., 2012). Uit onderzoek blijkt dat mensen met name een retributief/ vergeldend strafdoel voor ogen hebben (bijv. Carlsmith, 2006; Darley \& Pittman, 2003) en vorenstaande lijkt te indiceren dat het huidige strafklimaat dat doel niet (voldoende) realiseert. Dit verschil tussen wat gewone mensen 'willen' in termen

* $\quad$ Dit onderzoek is mogelijk gemaakt door de Gratama Stichting en het Leids Universiteits Fonds. 
van strafzwaarte en wat het rechtssysteem 'levert', wordt de punitiviteitskloof genoemd. Een van de verklaringen voor deze kloof is dat het publiek minder informatie of gebrekkige informatie over de strafrechtelijke procedure heeft vergeleken met rechters. Door mensen feitelijke en begrijpelijke informatie over een specifieke zaak te geven, neemt de algemene acceptatie toe (bijv. De Keijser e.a., 2007; De Groot-van Leeuwen e.a., 2015). Anderzijds blijkt echter dat in de beoordeling van exact dezelfde dossiers de geprefereerde straf van het publiek nog steeds strenger is dan van rechters (bijv. De Keijser e.a., 2007). Dit betekent dat er mogelijk andere factoren in het spel zijn die de ontevredenheid over de straf kunnen verklaren en beïnvloeden.

Of een slachtoffer hersteld wordt in de geleden schade zou een factor kunnen zijn die de punitiviteitskloof verder kan verklaren. Ondanks dat dit nog niet expliciet onderzocht is, lijkt er wel enige aanwijzing gevonden te kunnen worden voor deze assumptie in aanverwant onderzoek. Bijvoorbeeld het onderzoek van Roberts en Stalans (2004) naar de publieke opinie over rechtelijke procedures, inclusief slachtoffercompensatie, suggereert dat slachtoffercompensatie draagvlak geniet onder het algemene publiek (zie ook De Keijser, 2005). Eerdere studies lijken zelfs uit te wijzen dat waarnemers van onrecht het belangrijker vinden dat het slachtoffer wordt gecompenseerd dan dat de dader wordt bestraft (bijv. Lotz e.a., 2011; Van Doorn e.a., 2018a; 2018b). In deze studies waren participanten waarnemers van een zogenaamde 'dictator game', waarin een verdeler een bepaald geldbedrag mag verdelen tussen hemzelf en een ander. Participanten werden geconfronteerd met oneerlijke verdelingen van geld en konden eigen middelen inzetten om de verdeler/'dader' van onrecht te straffen of het 'slachtoffer' van de oneerlijke verdeling te compenseren voor het geleden verlies. Hierbij werd er vaker gekozen, en meer geld ingezet, voor compensatie dan voor straf. Ondanks dat deze studies nog ver af staan van de dagelijkse rechtspraktijk, en de slachtofferervaring in geval van een dictator game niet gelijk te trekken is met een slachtofferervaring van bijvoorbeeld geweldspleging, geven ze wel een dieper psychologisch inzicht in hoe observanten reageren op een confrontatie met onrecht. Deze dictator games onderstrepen bovendien tevens het belang dat mensen hechten aan herstel van het slachtoffer, hetgeen zelfs meer draagvlak geniet dan het straffen van de dader. Onderzoek laat (nog) geen eenduidige verklaring zien voor deze voorkeur. Een genoemde verklaring ligt in het idee van equity (Van Doorn e.a., 2014; 2019) of distributieve/verdelende rechtvaardigheid (zie Van den Bos e.a., 1997): de mate waarin onrecht wordt hersteld, rekening houdend met beide partijen (dader en slachtoffer). Enkel het straffen van de dader bereikt het doel van equity of distributieve rechtvaardigheid niet volledig (genoeg), het laat het slachtoffer immers nog steeds in een benadeelde positie achter.

\section{Slachtoffercompensatie in de praktijk}

Om te onderzoeken of slachtoffercompensatie een rol speelt in het verklaren van de punitiviteitskloof, is het van belang om te kijken naar hoe slachtoffercompensatie in de praktijk is vormgegeven. Wanneer een slachtoffer van criminaliteit 
schade is toegebracht, dan bestaat in Nederland de mogelijkheid om zich te voegen als benadeelde partij in het strafproces en een vordering tot schadevergoeding in te dienen (art. 51 Wetboek van Strafvordering). Zowel materiële als immateriële schade komt voor vergoeding in aanmerking, mits de behandeling van de vordering geen 'onevenredige belasting' voor het strafproces oplevert. Indien dat wel het geval is, zal het slachtoffer niet-ontvankelijk in zijn of haar vordering worden verklaard en zal hij/zij zich tot de civiele rechter moeten wenden om voor schadevergoeding in aanmerking te komen.

Bij de beoordeling van de door het slachtoffer ingediende vordering hanteert de strafrechter de vereisten van artikel 6:162 van het Burgerlijk Wetboek. Volgens dit artikel is degene die jegens een ander een onrechtmatige daad pleegt welke hem kan worden toegerekend, verplicht de schade die de ander dientengevolge lijdt, te vergoeden. Voor aansprakelijkheid uit hoofde van een onrechtmatige daad moet aan vijf vereisten zijn voldaan (Candido e.a., 2017):

- Er moet sprake zijn van een onrechtmatige daad.

- Deze onrechtmatige daad moet aan de dader (verdachte) kunnen worden toegerekend.

- Er moet sprake zijn van (enige) geleden of nog te lijden schade.

- Tussen de schade en de (onrechtmatige) daad moet een causaal verband bestaan.

- Er bestaat geen verplichting tot schadevergoeding wanneer de geschonden norm niet strekt tot bescherming tegen de schade zoals de benadeelde die heeft geleden (relativiteitsvereiste).

Indien aan deze vereisten is voldaan, wijst de strafrechter de vordering toe en is de dader gehouden tot vergoeding van de geleden schade. ${ }^{1}$ Indien niet aan deze criteria is voldaan, wordt de vordering afgewezen. Anders dan in geval van een niet-ontvankelijkverklaring van de vordering staat de weg naar de civiele rechter dan niet meer open (Candido e.a., 2017).

\section{Huidig onderzoek}

Het huidige onderzoek is gericht op het beantwoorden van de vraag in hoeverre een schadevergoeding aan het slachtoffer de mate waarin het algemene publiek zich kan vinden in een opgelegde straf beïnvloedt, controlerend voor het algemene oordeel dat mensen hebben over het strafrechtsysteem. Verwacht wordt dat wanneer een slachtoffer een schadevergoeding krijgt toegewezen, het algemene publiek zich meer kan vinden in de opgelegde straf dan wanneer een slachtoffer geen schadevergoeding krijgt toegewezen. Immers, als in de voorkeuren van mensen met betrekking tot de reactie op crimineel gedrag het herstellen van onrecht van het slachtoffer prevaleert boven het bestraffen van de dader, zoals in eerder onderzoek naar voren lijkt te komen, dan weegt een (zware) straf in het

1 Het komt ook regelmatig voor dat de vordering gedeeltelijk wordt toe- en gedeeltelijk wordt afgewezen. 
oog van het algemene publiek mogelijk niet op tegen de bijdrage die een schadevergoeding kan leveren.

Enige steun voor deze verwachting kan worden gevonden in een tweetal onderzoeken. Van de Calseyde en collega's (2013) tonen bijvoorbeeld aan dat de wens van mensen om een dader van diefstal te straffen verzwakt nadat ze lezen dat een slachtoffer van diefstal was verzekerd en de verzekeringsmaatschappij de schade zou compenseren. Een soortgelijke bevinding komt van Gromet en Darley (2006), die aantonen dat participanten lagere gevangenisstraffen toewijzen aan daders die met succes een herstelprocedure hadden voltooid (d.w.z., dader en slachtoffer zijn tot een overeenstemming gekomen) in vergelijking met een traditionele gerechtelijke procedure. Daarnaast illustreert de studie van Gromet e.a. (2012) dat wanneer mensen weten dat een slachtoffer tevreden is met het herstelrechtproces ('We hebben overeenstemming bereikt over wat de dader moet doen om de schade te herstellen die hij heeft veroorzaakt, en ik voel me heel tevreden'), mensen minder punitief zijn. Kortom, deze studies tonen aan dat de wens tot straffen verzwakt na schadeherstel van het slachtoffer. De huidige studie beoogt een stapje verder te gaan en te toetsen of de acceptatie van een bepaalde straf toeneemt na schadeherstel van het slachtoffer.

Enerzijds zijn inzichten die voortvloeien uit dit onderzoek relevant in het kader van (een verklaring voor) de punitiviteitskloof en daaraan gekoppeld de legitimiteit van het strafrechtsysteem: de mate waarin mensen vinden dat deze autoriteit het verdient om beslissingen te nemen die van invloed zijn op de uitkomsten van leden van de gemeenschap (Tyler, 2006). Zoals eerder vermeld, kan gesteld worden dat er onder een groot deel van het publiek een algemene visie gedragen wordt dat het huidige strafklimaat te mild is. In de literatuur wordt veelal verondersteld dat dit de legitimiteit van en het vertrouwen in het strafrechtsysteem kan ondermijnen. Middels het onderhavige onderzoek kan nagegaan worden in hoeverre schadeherstel van het slachtoffer die tendens kan beïnvloeden, en daarmee wellicht ook een positieve werking op de legitimiteit van het strafrechtsysteem kan bewerkstelligen. Dit is met name van belang wanneer we de ogenschijnlijk toenemende rol van het algemene publiek in het debat over misdaad en straf in ogenschouw nemen (bijv. Loader \& Sparks, 2011). Anderzijds biedt het onderzoek inzicht in de mogelijke effecten van het beter informeren van het algemene publiek over slachtoffercompensatie, hetgeen het publieke draagvlak voor slachtofferhulp en slachtoffergerichte interventies kan vergroten.

\section{Methode}

\section{Participanten}

Een totaal van $593^{2}$ deelnemers (49 procent vrouw, 51 procent man) uit het LISSpanel, bestaande uit een representatieve doorsnede van de Nederlandse bevolking, heeft deelgenomen aan het onderzoek (gemiddelde leeftijd: 53, range:

2 Een totaal van 682 mensen heeft de vragenlijst ingevuld, echter 89 van hen hadden de manipulatiecheck verkeerd ingevuld. Daardoor kunnen we niet met zekerheid zeggen dat zij het scenario goed gelezen/begrepen hadden. Zij zijn daarom niet meegenomen in de analyses. 


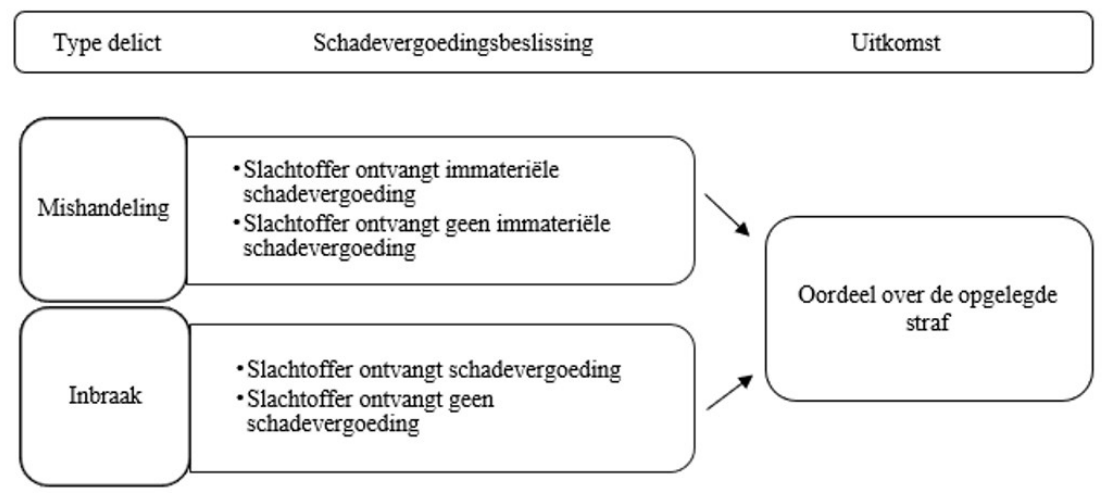

\section{Figuur 1 Visuele representatie van het onderzoeksdesign}

16-90). Het onderzoek kende een experimenteel onderzoeksdesign met twee (between subjects) experimentele factoren: type delict en schadevergoedingsbeslissing. Respondenten werden at random toebedeeld aan een van de vier experimentele condities in het 2 (type delict: mishandeling vs. inbraak) x 2 (schadevergoedingsbeslissing: geen schadevergoeding vs. wel schadevergoeding)-design. ${ }^{3}$ In figuur 1 is het onderzoeksdesign schematisch weergegeven.

Er is gekozen voor twee verschillende delicten, mishandeling en inbraak, omdat eerder onderzoek naar de voorkeur voor slachtoffercompensatie boven straf zich met name heeft gericht op vermogensdelicten zoals diefstal. Om te onderzoeken in hoeverre onze resultaten generaliseren naar geweldsdelicten, waar immers veelal immateriële schade een belangrijke rol speelt, is het onderscheid tussen inbraak en mishandeling aangebracht in ons experiment.

\section{Instrumentarium}

Participanten in de mishandelingconditie lazen het volgende vignet (deels gebaseerd op Bijleveld \& Elffers, 2010):

Twee onbekenden, Peter en Michel, staan te wachten op een metrostation. Het duurt nog vijf minuten voordat de metro komt. Tijdens het wachten zegt Peter tegen Michel: 'Wat kijk je?' Michel reageert met: 'Waar heb je het over, man?' Peter stompt vervolgens met een gebalde vuist onder het oog en tegen de neus van Michel, die er fracturen aan de oogkas en het neusbot aan overhoudt. Michel doet aangifte van zware mishandeling en een tijdje later wordt Peter aangehouden.

Peter wordt door de rechter schuldig bevonden voor zware mishandeling en krijgt een gevangenisstraf van 3 maanden.

3 In een pre-test is gekeken naar de relevantie van het toevoegen van een conditie waarin participanten niets lezen over een eventuele schadevergoeding. Omdat deze conditie geen significante resultaten opleverde, is er hier voor gekozen te focussen op wel/geen schadevergoeding. 
Participanten in de inbraakconditie lazen het volgende vignet (deels gebaseerd op Bijleveld \& Elffers, 2010):

Door het intikken van een wc-ruitje weet Peter bij de familie Jansen in te breken. De hele woning wordt overhoop gehaald en de laptop, de 40-inch led-tv en enkele sieraden worden uit de woning meegenomen. De familie (vader, moeder en twee kinderen) ligt op de bovenverdieping te slapen en heeft niets van de inbraak gemerkt. De familie Jansen doet aangifte van inbraak en een tijdje later wordt Peter aangehouden.

Peter wordt door de rechter schuldig bevonden voor inbraak in een woning en krijgt een gevangenisstraf van 3 maanden. ${ }^{4}$

Participanten in de schadevergoedingsconditie lazen na kennisgenomen te hebben van een van de delictsomschrijvingen en de opgelegde straf:

Michel heeft een verzoek tot schadevergoeding van immateriële schade ingediend, bestaande uit een bedrag van $€ 2000$. Dit verzoek wordt door de rechter toegewezen.

Participanten in de geen-schadevergoedingsconditie lazen na de delictsomschrijving en straf:

De familie Jansen heeft een verzoek tot schadevergoeding van immateriële schade ${ }^{5}$ ingediend, bestaande uit een bedrag van $€ 2000$. Dit verzoek wordt door de rechter niet toegewezen.

Vervolgens kregen alle participanten een aantal vragen voorgelegd, die zij konden beantwoorden op een schaal van 1 tot 7 . De afhankelijke variabele was gericht op hun mening ten aanzien van de opgelegde gevangenisstraf van 3 maanden (zoals vermeld in het vignet). Tevens waren we geïnteresseerd in de meer algemene mening die het publiek heeft over het strafrechtelijk systeem (gebaseerd op Elffers e.a., 2007) en het slachtoffer (gebaseerd op Lens e.a., 2017), die niet direct betrekking heeft op de concrete aspecten genoemd in het vignet. Zie tabel 1 voor een overzicht van de gestelde vragen.

Tot slot is er gevraagd naar een aantal demografische gegevens en hebben de participanten een manipulatiecheck voltooid. In deze check is gevraagd welk delict er

4 Deze gevangenisstraf is voor beide delicten gelijk en is gebaseerd op oriëntatiepunten voor straftoemeting opgesteld door het Landelijk Overleg Vakinhoud Strafrecht (LOVS).

5 In de vragenlijst konden participanten middels een mouse-over de definitie van immateriële schade krijgen. Hierbij komt de betekenis van het woord in beeld als men met de muis (of vinger in het geval van een smartphone of tablet) over het woord gaat. Hiervoor is de definitie van rechtspraak.nl gehanteerd: 'Schade die veroorzaakt is door verdriet, smart of geestelijk gemis. Deze schade is (in tegenstelling tot materiële schade) niet direct in geld uit te drukken. De vergoeding die wordt uitgekeerd om immateriële schade te vergoeden heet smartengeld.' 
werd beschreven (mishandeling/inbraak) en of de rechter een immateriële schadevergoeding had toegewezen (ja/nee).

\section{Data-analyse}

Allereerst is gekeken in welke mate participanten de opgelegde straf te hoog of te laag vinden door middel van een one sample $t$-toets. Hiermee is getoetst of de gemiddelde score afwijkt van het midden van de schaal ('ik zou dezelfde straf opgelegd hebben'). Vervolgens, om inzicht te krijgen in de hoofd- en interactieeffecten van de factoren 'type delict' en 'schadevergoedingsbeslissing' op de vraag wat mensen van de opgelegde straf vinden, is een ANOVA (F-toets) uitgevoerd.

Naast de waardering van strafoplegging is gevraagd naar een meer algemeen oordeel dat het algemene publiek heeft betreffende het strafrechtsysteem en het slachtoffer. Omdat het onderzoek een experimentele opzet met random toewijzing van participanten heeft en er daarmee van uitgegaan kan worden dat mensen met verschillende eigenschappen/meningen over de condities evenredig verspreid zitten, worden deze variabelen niet zozeer als controlevariabelen maar als groepsvariabelen meegenomen. Meer specifiek betekent dat dat er getoetst wordt of er een effect van de schadevergoedingsbeslissing op de waardering van de opgelegde straf bestaat onder groepen participanten met een bepaalde mening over het strafrechtelijk systeem en het slachtoffer. Deze aanvullende analyses geven ons, naast de effecten van de experimentele manipulaties, inzicht in hoeverre een potentiële invloed van schadevergoedingsbeslissing met name, of enkel, onder specifieke groepen met een bepaalde mening over het strafrechtelijk systeem bestaat. Ook hierbij worden ANOVA's (F-toetsen) uitgevoerd.

\section{Resultaten}

\section{Oordeel over opgelegde straf}

Een overzicht van gemiddelden en standaarddeviaties van deze items, per conditie, is te vinden in tabel 2. Op de vraag wat participanten vinden van de opgelegde straf, scoren participanten gemiddeld 3.12 ( $S D=1.30)$, hetgeen lager is dan het midden van de schaal (4: 'ik zou dezelfde straf opgelegd hebben'; $t=16.36, p<$. 001), ongeacht het type delict (mishandeling/inbraak) en of schadevergoeding wel of niet is toegewezen. Er werd dan ook geen interactie-effect gevonden, $F(1$, 589)=0.66, $p=.417, \eta p^{2}=.001$, en geen hoofdeffecten, $F(1,589)=3.28, p=.070$, $\eta \mathrm{p}^{2}=.006$ (type delict); $F(1,589)=1.01, p=.315, \eta \mathrm{p}^{2}=.002$ (schadevergoedingsbeslissing). Dit betekent dat participanten de opgelegde straf in het algemeen te laag vinden.

Aanvullende analyses: algemeen oordeel strafrechtelijk systeem en slachtoffer(s)

Hierna volgt een overzicht van de algemene scores onder het algemene publiek met betrekking tot hun oordeel over het strafrechtelijk systeem en de/het slachtoffer(s). Daarnaast is getoetst of er wel een effect van de schadevergoedingsbe- 
Tabel 1 Items en bijbehorende schalen

\begin{tabular}{ll}
\hline Items vragenlijst & Schaal \\
\hline Wat vindt u van de hoogte van de door de rechter & I (te laag) \\
opgelegde gevangenisstraf van 3 maanden? & $\begin{array}{l}\text { (ik zou dezelfde straf opgelegd heb- } \\
\text { ben) } \\
7 \text { (te hoog) }\end{array}$
\end{tabular}

Oordeel strafrechtelijk systeem

In hoeverre vindt u dat misdaden in Nederland over het I (helemaal niet te licht bestraft) algemeen te licht worden bestraft?

$$
7 \text { (veel te licht bestraft) }
$$

In hoeverre hebt u vertrouwen in het Nederlandse straf- I (helemaal geen vertrouwen rechtsysteem?

7 (heel veel vertrouwen)

In hoeverre staat $\mathrm{u}$ achter de manier waarop rechters in I (sta er helemaal niet achter) Nederland doorgaans rechtspreken?

7 (sta er heel erg achter)

In hoeverre vindt $\mathrm{u}$ het belangrijk dat een slachtoffer een I (helemaal niet belangrijk) schadevergoeding voor immateriële schade kan indienen?

In hoeverre denkt u dat de/het slachtoffer(s) iets had(den) kunnen doen om het delict te voorkomen?

\author{
7 (heel erg belangrijk) \\ I (helemaal niets aan kunnen doen)
}

7 (heel veel aan kunnen doen)

slissing op de waardering van de opgelegde straf is onder bepaalde groepen participanten.

Lichte bestraffing. Participanten vinden dat er over het algemeen te licht bestraft wordt in Nederland $(M=5.21, S D=1.41)$. De groep participanten die een hoge score heeft op dit item is groot (score 5-7: $n=438$ vs. score 1-3: $n=65$ ). Voor de grote groep participanten die in hoge mate vindt dat er in het algemeen te licht bestraft wordt, is getoetst of er voor hen een significant effect van de schadevergoedingsbeslissing op de waardering van de opgelegde straf bestaat. ${ }^{6}$ Dat was niet het geval: $F(1,436)=1.82, p=.179, \eta p^{2}=.004$.

Mate van vertrouwen in het strafrechtsysteem. De mate van vertrouwen dat participanten hebben in het rechtssysteem $(M=4.22, S D=1.53)$ is gemiddeld te noemen. Getoetst is of er een invloed van de schadevergoedingsbeslissing is op de waardering van de opgelegde straf, voor laag (score 1-3; $n=185$ ) en hoog (score 5-7; $n=271$ ) vertrouwen in het strafrechtsysteem. Dit was niet het geval: er werd geen schadevergoedingsbeslissing ${ }^{*}$ mate van vertrouwen interactie-effect gevonden, $F(1,452)=0.29, p=.593, \eta p^{2}=.001$.

6 Vanwege de grote onevenredigheid in participantaantallen is een betrouwbare vergelijking tussen de twee groepen niet mogelijk. 
Tabel 2 Gemiddelden (en standaarddeviaties) per conditie

\begin{tabular}{|c|c|c|c|c|}
\hline & \multicolumn{4}{|c|}{ Conditie } \\
\hline & \multicolumn{2}{|c|}{ Mishandeling } & \multicolumn{2}{|c|}{ Inbraak } \\
\hline & $\begin{array}{l}\text { Wel schade- } \\
\text { vergoeding } \\
(n=150)\end{array}$ & $\begin{array}{l}\text { Geen schade- } \\
\text { vergoeding } \\
(n=\mid 44)\end{array}$ & $\begin{array}{l}\text { Wel schade- } \\
\text { vergoeding } \\
(n=130)\end{array}$ & $\begin{array}{l}\text { Geen schade- } \\
\text { vergoeding } \\
(n=169)\end{array}$ \\
\hline & M (SD) & $M(S D)$ & $M(S D)$ & $M(S D)$ \\
\hline \multirow{2}{*}{$\begin{array}{l}\text { Zich kunnen vin- } \\
\text { den in de hoogte } \\
\text { van de straf }\end{array}$} & $3.32(1.22)$ & $3.12(1.37)$ & $3.04(1.37)$ & $3.02(1.25)$ \\
\hline & \multicolumn{2}{|c|}{$3.22(1.30)$} & \multicolumn{2}{|c|}{$3.03(1.31)$} \\
\hline
\end{tabular}

Achter manier van rechtspreken staan. Ook de mate waarin participanten achter de manier waarop rechters in Nederland doorgaans rechtspreken staan, is gemiddeld te noemen $(M=4.24, S D=1.46)$. Omdat de groep participanten die in lage mate achter de manier van rechtspreken staat (score $1-3 ; n=385$ ) groter is dan de groep participanten die in hoge mate achter de manier van rechtspreken staat (score 5-7; $n=102$ ), is voor de eerste groep gekeken of er voor hen een significant effect van de schadevergoedingsbeslissing op de waardering van de opgelegde straf bestaat. Dat was niet het geval: $F(1,383)=1.48, p=.224, \eta p^{2}=.004$.

Belang immateriële schadevergoeding. In het algemeen wordt er een hoge score gevonden voor de mate waarin een schadevergoeding voor immateriële schade als belangrijk wordt gevonden $(M=5.47, S D=1.20)$. Omdat de groep participanten die in hoge mate vindt dat de mogelijkheid om een immateriële schadevergoeding aan te vragen van belang is (score $5-7 ; n=503$ ) veel groter is dan de groep participanten die dat in lage mate vindt (score $1-3 ; n=26$ ), is enkel voor de eerste groep gekeken of er een significant effect van de schadevergoedingsbeslissing op de waardering van de opgelegde straf bestaat. Dat was het geval: $F(1,501)=4.35, p=$. $038, \eta \mathrm{p}^{2}=.009$. Kortom, mensen die de mogelijkheid tot een schadevergoeding wel van belang vinden, maar lazen dat de/het slachtoffer(s) geen schadevergoeding toegewezen hebben/heeft gekregen, vinden de opgelegde straf in meerdere mate te laag $(M=2.92, S D=1.28)$ dan participanten uit deze groep die lazen dat de/het slachtoffer(s) wel een schadevergoeding toegewezen hebben/heeft gekregen $(M=3.16, S D=1.31)$.

Schuld slachtoffer(s). Over het algemeen kan gesteld worden dat participanten niet tot nauwelijks vinden dat de/het slachtoffer(s) blaam treft. Zowel op de vraag of ze denken dat het slachtoffer iets had kunnen doen om het delict te voorkomen $(M=2.82, S D=1.59)$, als op de vraag of het slachtoffer schuldig is aan hetgeen hem is overkomen $(M=1.70, S D=1.19)$, wordt laag gescoord. Ook wanneer we voor deze variabelen groepen maken, zien we dat er sprake is van onevenredige groepsaantallen. Het aantal participanten dat vindt dat het slachtoffer iets had kunnen doen (score 5-7; $n=102$ ) en schuldig is aan hetgeen hem is overkomen (score 5-7; $n=23$ ), is veel kleiner dan de groep participanten die dat niet vindt (score 1-3; $n=385$ en $n=532$, respectievelijk). Enkel voor de grootste groepen is gekeken of er een significant effect van de schadevergoedingsbeslissing op de waardering van de 
opgelegde straf bestaat. Dat was niet het geval: $F(1,383)=1.48, p=.224, \eta p^{2}=.004$ (slachtofferschap kunnen voorkomen) en $F(1,530)=1.35, p=.247, \eta p^{2}=.003$ (slachtoffer schuldig).

\section{Discussie}

In de huidige studie is onderzocht in hoeverre het toewijzen van slachtoffercompensatie van invloed is op het oordeel dat het algemene publiek heeft in een door de rechter opgelegde straf. Uit de resultaten blijkt dat het wel of niet toewijzen van een immateriële schadevergoeding, in het geval van zowel het delict mishandeling als inbraak, geen effect heeft op de mate waarin het algemene publiek zich kan vinden in de door de rechter opgelegde straf. Er is bovendien geen significant effect van de schadevergoedingsbeslissing op de waardering van de opgelegde straf onder groepen participanten met een bepaalde mening over het strafrechtelijk systeem en over het slachtoffer (het in hoge of lage mate eens zijn met de stelling dat er in Nederland te licht bestraft wordt; een hoge/lage mate van vertrouwen hebben in het strafrechtsysteem; in een hoge/lage mate achter de manier waarop rechters in Nederland doorgaans rechtspreken staan; en in hoge/lage mate vinden dat de/het slachtoffer(s) blaam treft en schuldig zijn/is aan hetgeen hun/hem is overkomen).

Kortom, op basis van de huidige uitkomsten blijkt dat met het toewijzen van schadevergoeding de punitiviteitskloof noch gedicht noch verminderd kan worden. Dit wordt bevestigd door de bevinding dat het algemene publiek vindt dat er over het algemeen te licht bestraft wordt in Nederland, hetgeen ook in veelvuldig eerder onderzoek is gevonden (bijv. De Keijser e.a., 2007; Elffers \& De Keijser, 2004; De Keijser \& Elffers, 2009; Dekker e.a., 2012). Toch is enige nuance hier op zijn plek: participanten geven ook aan dat zij het belangrijk vinden dat een slachtoffer een schadevergoeding voor immateriële schade kan indienen. Sterker nog, aanvullende analyses tonen aan dat de groep mensen die hoog scoren op dit belang van een immateriële schadevergoeding, maar lazen dat de/het slachtoffer(s) die schadevergoeding niet toegewezen had(den) gekregen, met name vonden dat de opgelegde straf te laag was.

Waarom slachtoffercompensatie geen invloed blijkt te hebben op de mate waarin mensen zich kunnen vinden in de opgelegde straf kan met meerdere factoren te maken hebben. Allereerst, wanneer we kijken naar onderzoek dat verschillende strafdoelen in kaart brengt, dan blijkt dat mensen met name een retributief strafdoel hebben (bijv. Carlsmith, 2006; Darley \& Pittman, 2003). Compensatie van het slachtoffer dient dat doel over het algemeen niet, hetgeen een verklaring zou kunnen zijn waardoor het in de huidige studie geen invloed had op de 'tevredenheid' met de opgelegde straf. Dit betekent niet dat mensen compensatie niet belangrijk vinden, hetgeen ook in de onderhavige studie gevonden wordt (zie ook De Keijser e.a., 2002). Gromet en Darley (2009), bijvoorbeeld, toonden aan dat deelnemers het straffen van de dader van belang vinden, maar compensatie van het slachtoffer ook nodig achten. Oftewel, 
'(...) people view the satisfaction of multiple justice goals as an appropriate and just response to wrongdoing, which allows for a possible reconciliation between the "conflicting" goals of restorative and retributive justice.' (p. 1)

In het verlengde hiervan ligt de verklaring dat straf en herstel niet per se rivaliserende concepten hoeven te zijn in de voorkeur van mensen (De Keijser, 2000; De Keijser e.a., 2002). Anders gezegd: een strafdoel als vergelding hoeft geen samenhang te hebben met het belang dat aan herstel gehecht wordt. In die zin kan de voorkeur voor een harde straf voor de pleger van een misdrijf ook samengaan met de sterke wens dat daarnaast een herstelgerichte interventie plaatsvindt. Pas op het moment dat in de praktijk straf en herstel niet kunnen co-existeren, dient noodzakelijkerwijs gekozen te worden. Dan valt te bezien in hoeverre de keuze voor herstel prevaleert boven de behoefte aan vergelding. Ons experiment heeft een dergelijke keuze niet afgedwongen en bevestigt nu de normatieve onafhankelijkheid van herstel enerzijds en doelen als vergelding anderzijds in de voorkeuren van mensen.

De vermeende discrepantie van de huidige resultaten met eerdere bevindingen kan ook te maken hebben met andere aspecten van het onderzoeksdesign. In eerdere studies (bijv. in zogenaamde dictator games) kregen participanten de mogelijkheid zelf de straf of compensatie uit te delen in plaats van dat een rechter dat bepaalt en toewijst. Daarnaast is het toebedelen van straf en/of compensatie in dat soort studies doorgaans ook nog kostbaar; participanten dienen eigen geld in te zetten om de straf of compensatie mogelijk te maken. Er zou beargumenteerd kunnen worden dat mensen daardoor wellicht bewustere beslissingen maken over de mate van straf (en compensatie) dan in het onderhavige onderzoek het geval was. Onderzoek toont inderdaad aan dat straffen een initiële, automatische of heuristische respons is na onrecht (bijv. Aharoni \& Fridlund, 2012; Carlsmith, 2006; Gromet \& Darley, 2006; Sargent, 2004), maar dat mensen minder punitief worden wanneer zij bijvoorbeeld geconfronteerd worden met de kosten van straffen (Aharoni e.a., 2019). Bovendien, wanneer mensen weten dat het slachtoffer tevreden is over de slachtoffercompensatie, worden zij minder punitief (Gromet e.a., 2012). Mogelijk zorgt het saillant maken van deze aspecten wel voor een invloed van de toewijzing van slachtoffercompensatie op de tevredenheid met een opgelegde straf. Daaraan gerelateerd zou de tevredenheid onder het algemene publiek over de mate van slachtoffercompensatie tevens een rol kunnen spelen. In de huidige studie hebben we onderzocht in hoeverre participanten het van belang vinden dat een slachtoffer een immateriële schadevergoeding kan indienen, niet hoe zij de schadevergoeding in het vignet (2.000 euro) waarderen. Mogelijk heeft de hoogte van de schadevergoeding wel een wisselwerking met de waardering van de hoogte van de straf, zoals dat in dictator games ook gevonden wordt. Kortom, het draait niet (enkel) om het geven van informatie, maar (ook) om de inhoud van die informatie.

\section{Limitaties}

Het huidige onderzoek kent een aantal limitaties waar rekening mee gehouden dient te worden in de waardering van de resultaten. Allereerst is er in de studie 
gebruik gemaakt van een vignet; participanten wordt gevraagd een oordeel te vellen op basis van een hypothetische situatie met beperkte informatie. Het is mogelijk dat participanten op basis hiervan situaties anders beoordelen dan ze in werkelijkheid zouden doen. Toch biedt het gebruik van vignetten ook een belangrijk voordeel: het maakt het mogelijk om relatief complexe materie te toetsen in een overzichtelijke situatie, waarin de invloed van een bepaalde factor makkelijker bepaald en gecontroleerd kan worden, en waarin zo min mogelijk sprake is van storende factoren (Hughes \& Huby, 2004).

Een andere limitatie van de huidige studie betreft het hoge aantal participanten dat de manipulatiecheck foutief heeft ingevuld. Deze participanten zijn niet meegenomen in de analyses, omdat we er niet zeker van kunnen zijn dat het vignet juist is gelezen en de responsen daadwerkelijk een gevolg zijn van het vignet zoals dit bedoeld is (bijv. Hauser e.a., 2018; Kane \& Barabas, 2019). Op de gehele sample bezien betreft het een percentage van 13 procent, wat in overeenstemming is met percentages die in andere experimentele studies gevonden worden (Thomas \& Clifford, 2017). Tevens is er in onze uiteindelijke sample een goede man-vrouwbalans en diversiteit in leeftijd te zien, hetgeen lijkt te indiceren dat het excluderen van participanten die de manipulatiecheck foutief hebben ingevuld niet voor een disbalans/bias in de sample heeft gezorgd.

\section{Conclusie}

In het huidige experiment is onderzocht of de aanwezigheid van slachtoffercompensatie van invloed is op oordelen over straf, hetgeen, ook na gecontroleerd te hebben voor het algemene oordeel dat mensen hebben over het strafrechtsysteem, niet gevonden wordt. Er wordt hierin geen verklaring gevonden voor de punitiviteitskloof. Toch wordt het door het publiek belangrijk gevonden dat er voor slachtoffers de mogelijkheid bestaat om een schadevergoeding voor immateriële schade in te dienen. Dit lijkt te indiceren dat er waarde wordt gehecht aan zowel straf als herstel. Het algemene publiek wordt doorgaans echter beperkt geïnformeerd over het laatste, terwijl het kansen biedt voor het vergroten van het publieke draagvlak voor slachtoffergerichte interventies.

\section{Literatuur}

Aa, S. van der \& Groenhuijsen, M. (2012). Slachtofferrechten in het strafproces: drie stapjes naar voren en een stapje terug? Ars Aequi, 9, 603-611.

Aa, S. van der, Groenhuijsen, M. \& Pemberton, A. (2013). Strafrechtelijke beschermingsbevelen en mediation binnen het strafproces: over nieuwe privaatrechtelijke ondertonen in het strafrecht. Ars Aequi, 6, 546-557.

Aharoni, E. \& Fridlund, A.J. (2012). Punishment without reason: isolating retribution in lay punishment of criminal offenders. Psychology, Public Policy, and Law, 18(4), 599-625. 
Aharoni, E., Kleider-Offutt, H.M., Brosnan, S.F. \& Watzek, J. (2019). Justice at any cost? The impact of cost-benefit salience on criminal punishment judgments. Behavioral Sciences and the Law, 37(1), 38-60.

Barber, J. \& Doob, A.N. (2004). An analysis of public support for severity and proportionality in the sentencing of youthful offenders. Canadian Journal of Criminology and Criminal Justice, 46(3), 327-342.

Bijleveld, C. \& Elffers, H. (2010). Sekse en straftoemeting. Tijdschrift voor Criminologie, 52(4), 365-373.

Bos, K. van den, Lind, E.A., Vermunt, R. \& Wilke, H.A.M. (1997). How do I judge my outcome when I do not know the outcome of others? The psychology of the fairness process effect. Journal of Personality and Social Psychology, 72(5), 1034-1046.

Calseyde, P.P.F.M. van de, Keren, G. \& Zeelenberg, M. (2013). The insured victim effect: when and why compensating harm decreases punishment recommendations. Judgment and Decision Making, 8(2), 161-173.

Candido, J., Hoendervoogt, M., Dam, P. van \& Gest, M. (2017). Slachtoffer en de rechtspraak. Handleiding voor de strafrechtspraktijk. Den Haag: Raad voor de rechtspraak.

Carlsmith, K.M. (2006). The roles of retribution and utility in determining punishment. Journal of Experimental Social Psychology, 42(4), 437-451.

Darley, J.M. \& Pittman, T.S. (2003). The psychology of compensatory and retributive justice. Personality and Social Psychology Review, 7(4), 324-336.

Dekker, P., Ridder, J. den \& Schnabel, P. (2012). Burgerperspectieven 2012-1. Den Haag: Sociaal en Cultureel Planbureau.

Doorn, J. van, Zeelenberg, M. \& Breugelmans, S.M. (2014). Anger and prosocial behavior. Emotion Review, 6(3), 261-268.

Doorn, J. van, Zeelenberg, M. \& Breugelmans, S.M. (2018a). An exploration of third parties' preference for compensation over punishment: six experimental demonstrations. Theory and Decision, 85(3-4), 333-351.

Doorn, J. van, Zeelenberg, M., Breugelmans, S.M., Berger, S. \& Okimoto, T.G. (2018b). Prosocial consequences of third-party anger. Theory and Decision, 84(4), 585-599.

Doorn, J. van, Zeelenberg, M. \& Breugelmans, S.M. (2019). Emotional experience and prosocial behavior in observers of unjust situations. Applied Psychology in Criminal Justice, 15(1), 41-59.

Elffers, H. \& Keijser, J.W. de (2004). Het geloof in de kloof: wederzijdse beelden van rechters en publiek. In: J.W. de Keijser \& H. Elffers (eds.). Het maatschappelijk oordeel van de strafrechter. De wisselwerking tussen rechter en samenleving. Den Haag: Boom Juridische uitgevers, 53-84.

Elffers, H., Keijser, J.W. de, Koppen, P.J. van \& Haeringen, L. van (2007). Newspaper juries. A field experiment concerning the effect of information on attitudes towards the criminal justice system. Journal of Experimental Criminology, 3(2), 163-181.

Gromet, D.M. \& Darley, J.M. (2006). Restoration and retribution: how including retributive components affects the acceptability of restorative justice procedures. Social Justice Research, 19(4), 395-432.

Gromet, D.M. \& Darley, J.M. (2009). Punishment and beyond: achieving justice through the satisfaction of multiple goals. Law and Society Review, 43(1), 1-38.

Gromet, D.M., Okimoto, T.G., Wenzel, M. \& Darley, J.M. (2012). A victim-centered approach to justice? Victim satisfaction effects on third-party punishments. Law and Human Behavior, 36(5), 375-389.

Groot-van Leeuwen, L. de, Laemers, M. \& Sportel, I. (2015). Het vonnis beter uitgelegd? Maatschappelijke effecten van beter motiveren in de strafrechtspraak. Research Memorandum 10/2. Den Haag: Raad voor de rechtspraak. 
Hauser, D.J., Ellsworth, P.C. \& Gonzalez, R. (2018). Are manipulation checks necessary? Frontiers in Psychology, 9, 1-10.

Hough, M. \& Roberts, J.V. (1998). Attitudes to punishment: findings from the British Crime Survey. London: Home Office.

Hughes, R. \& Huby, M. (2004). The construction and interpretation of vignettes in social research. Social Work and Social Sciences Review, 11(1), 36-51.

Hutton, N. (2005). Beyond populist punitiveness? Punishment \& Society, 7(3), 243-258.

Kane, J.V. \& Barabas, J. (2019). No harm in checking: using factual manipulation checks to assess attentiveness in experiments. American Journal of Political Science, 63(1), 234-249.

Keijser, J.W. de (2000). Punishment and purpose: from moral theory to punishment in action. Amsterdam: Rosenberg Publishers.

Keijser, J.W. de (2005). Het relatieve draagvlak voor herstel. Tijdschrift voor Herstelrecht, $5(1), 35-40$.

Keijser, J.W. de \& Elffers, H. (2009). Cross-jurisdictional differences in punitive public attitudes? European Journal on Criminal Policy and Research, 15(1-2), 47-62.

Keijser, J.W. de, Koppen, P.J. van \& Elffers, H. (2007). Bridging the gap between judges and the public? A multi-method study. Journal of Experimental Criminology, 3(2), 131-161.

Keijser, J.W. de, Leeden, R. van der \& Jackson, J.L. (2002). From moral theory to penal attitudes and back: a theoretically integrated modeling approach. Behavioral Sciences \& the Law, 20(4), 317-335.

Laxminarayan, M., Bosmans, M., Porter, R. \& Sosa, L. (2013). Victim satisfaction with criminal justice: a systematic review. Victims \& Offenders, 8(2), 119-147.

Lens, K.M.E., Pemberton, A. \& Groenhuijsen, M.S. (2010). Het spreekrecht in Nederland: een bijdrage aan het emotioneel herstel van slachtoffers? Tilburg: PrismaPrint Tilburg.

Lens, K.M.E., Doorn, J. van, Pemberton, A., Lahlah, E. \& Bogaerts, S. (2017). One rule for the goose, one for the gander? Wrongfulness and harmfulness in determining reactions to offenders and victims of crime. European Journal of Criminology, 14(2), 183-199.

Loader, I. \& Sparks, R. (2011). Public criminology? London: Routledge.

Lotz, S., Okimoto, T.G., Schlösser, T. \& Fetchenhauer, D. (2011). Punitive versus compensatory reactions to injustice: emotional antecedents to third-party interventions. Journal of Experimental Social Psychology, 47(2), 477-480.

Mattinson, J. \& Mirrlees-Black, C. (2000). Attitudes to crime and criminal justice: findings from the 1998 British Crime Survey. London: Home Office.

Roberts, J.V. \& Hough, M. (2002). Public attitudes to punishment: the context. In: J.V. Roberts \& M. Hough (eds.). Changing attitudes to punishment: public opinion, crime and justice. Cullompton, Devon: Willan, 1-14.

Roberts, J.V. \& Stalans, L.J. (2004). Restorative sentencing: exploring the views of the public. Social Justice Research, 17(3), 315-334.

Sargent, M.J. (2004). Less thought, more punishment: need for cognition predicts support for punitive responses to crime. Personality and Social Psychology Bulletin, 30(11), 1485-1493.

Scheirs, V., Beyens, K. \& Keijser, J.W. de (2009). De slachtoffergerichte dimensie in rechterlijk denken. Tijdschrift voor Herstelrecht, 9(1), 7-19.

Thomas, K.A. \& Clifford, S. (2017). Validity and Mechanical Turk: an assessment of exclusion methods and interactive experiments. Computers in Human Behavior, 77, 184-197.

Tyler, T.R. (2006). Psychological perspectives on legitimacy and legitimation. Annual Review of Psychology, 57(1), 375-400. 